\title{
Molluscan Models: Crepidula fornicata
}

\author{
Authors: J. Q. Henry ${ }^{1,3}$ and D. C. Lyons ${ }^{2}$
}

${ }^{1}$ University of Illinois, Dept. Cell \& Developmental Biology, 601 S. Goodwin Ave. Urbana, IL 61801

${ }^{2}$ Duke University, Biology Department ,4115 French Family Science Center, Durham, NC 27708

${ }^{3}$ Author for Correspondence

\begin{abstract}
:
Gastropod snails in the genus Crepidula have emerged as model systems for studying a metazoan super clade, the Spiralia. Recent work on one species in particular, $C$. fornicata, has produced high-resolution cell lineage fate maps, details of morphogenetic events during gastrulation, key insights into the molecular underpinnings of early development, and the first demonstration of CRISPR/Cas9 genome editing in the Spiralia. Furthermore, invasive species of Crepidula are a significant ecological threat, while one of these, C. fornicata, is also being harvested for food. This review highlights progress towards developing these animals as models for evolutionary, developmental, and ecological studies. Such studies have contributed greatly to our understanding of biology in a major clade of bilaterians. This information may also help us to control and cultivate these snails.
\end{abstract}

\section{Crepidula, model representatives of the Spiralia}

The genus Crepidula comprises the "slipper snails", members of the caenogastropod family Calyptraeidae within the Gastropoda (Fig 1A-B). Adult slipper snails have a limpet-like morphology with a posterior apex and internal septum that covers much of the visceral mass (Fig 1A-B; Collin and Cipriani, 2003; Henry et al., 2010a). The presence of this internal shelf gives the shell the appearance of a small slipper when the animal is removed. As members of the Mollusca, slipper snails represent one of 14 phyla that comprise the metazoan superphylum Spiralia, the largest clade of bilaterian metazoans (Fig. 2A). Molluscs represent the second most speciose animal phylum and slipper snails lie within the molluscan class Gastropoda (Fig. 2B). Spiralia exhibit diverse larval and adult body plans, yet many representatives share a stereotypical mode of development including a conserved fate map and cleavage pattern, referred to as spiral cleavage (Figs. 2, 3A-E; Henry, 2014). In fact, Edwin G. Conklin (1897) formalized the spiral cleavage cell lineage nomenclature while studying Crepidula at the Marine Biological Laboratory in Woods Hole, MA. The conserved spiral cleavage pattern offers a unique opportunity to discover how diverse body plans evolved from a similar starting point, by studying homologous cell lineages at the single cell level. Yet, compared to deuterostomes and ecdysozoans, spiralians have received much less attention as subjects for understanding cell and molecular mechanisms controlling development.

\section{Models for studying life history strategies}

The Crepidula genus contains nearly 60 species, and their phylogenetic relationships have been well established (Hoagland, 1977, 1984, 1985; Collin, 2000a, 2001, 2003a, b, 2004; Henry et al., 2010). These species exhibit a wide array of life history strategies. For instance, species such as $C$. fornicata exhibit indirect, planktotrophic development (Fig 1A, C), while others, including $C$. convexa and $C$. atrasolea, have life cycles that involve direct forms of development (Fig. 1B, D-G, Collin, 2000b, 2001, 2003c, 2004). Species like C. onyx and C. navicella exhibit adelphophagic modes of development where embryos consume sibling, non-developing or aborted nurse eggs and embryos contained in the egg capsules (Collin and Spangler, 2012; 
Lesoway et al., 2014). Adelphophagy could permit retention of larval features and provide flexibility for reinvention of planktotrophic modes of development, which is seen in some other closely related species (Collin, 2004; Lesoway et al., 2014). The wide range of developmental strategies and solid phylogenetic framework make this group well-suited for studies to examine life history evolution. Crepidula have also been used to examine larval development, growth and metamorphosis, with many studies examining how metamorphic competence arises in planktotrophic forms (e.g., Pechenik et al, 1996a,b, 2007; Taris et al., 2009). The larva must grow to a certain size to reach metamorphic competence, and a recent study by Padilla et al. (2014) using $C$. fornicata found that achieving metamorphic competence is related to food abundance, regardless of diet composition or temperature.

\section{Models for studying sex change}

Calyptraeid snails have also been used to study sexual development and sex change (Fig 1AB, G). They are protandric hermaphrodites, which means that following an initial juvenile phase, all individuals first become reproductive males and subsequently transition to reproductive females. Isolated males will transition to females more quickly, and females grow at a much faster rate. The presence of females delays males from becoming females (Coe, 1936, 1938, 1953; Hoagland, 1978; Collin et al., 2005). Recent studies found that the factor(s) controlling sex change and growth in $C$. fornicata appear to be contact-dependent, and not water-born substances, as had been previously assumed (Cahill et al., 2015; Carrillo-Baltodana and Collin, 2015).

\section{Invasive Crepidula-pest or pastry?}

C. fornicata is native to the American north eastern Atlantic, but has been introduced into the waters of Europe, including the Mediterranean Sea, and the Northern Coast of France, Spain, the North Sea, the British Isles, Japan, Uruguay, and the West and Pacific Northwest coastal areas of America (Orton, 1912a; Spärck, 1935, 1950; Korringa, 1942; Chippenfield, 1951; Walne, 1956; Hessland, 1951; Louis, 1963; Dommasnes and Schram, 1973; Barnes et al., 1973; Minchin et al., 1995; Sjøtun, 1997; Blanchard, 2009; Chauvaud et al., 2000;

Hedeselskabet, 2003; Thieltges et al., 2003; Nehls, et al., 2006; Collin et al., 2006; 2009; Riera, 2007; Viard et al., 2006; Moulin et al., 2007). Reports indicate that $C$. fornicata may have first appeared in European waters sometime towards the end of the $19^{\text {th }}$ century, presumably associated with the importation of American Shellfish (e.g., oysters). Specimens may have also been attached to the hulls, or released from ballast water of Allied warships visiting the region during the World Wars (Walne, 1956; Minchin et al., 1995; Blanchard, 1997; Sauriau et al., 1998; Richard et al., 2006; Minchin, 2007; Rayment, 2008). Another species, C. onyx, which is native to Southern California, has invaded waters of the Pacific Northwest, and Hong Kong (Huang et al., 1983; Holm, 2006).

There is tremendous concern over the ecological impact of these invasive snails (Viard, 2010). Crepidula are highly effective filter feeders that compete for available phytoplankton (Johnson, 1972; Newell and Kofoed, 1977; Beninger et al., 2007; Decottignies et al., 2007a; Blanchard et al., 2008). Their feces and pseudofeces (undigested food) also alter turbidity and surrounding sediment beds (Loomis \& van Nieuwenhuyze 1985; Ehrhold et al., 1998; le Pape et al., 2004), and the adults are highly fecund, with juveniles settling on hard substrates, including local shellfish to compete for space and thus, act in a bio-fouling capacity (de Montaudouin et a., 1999; Thieltges 2005b; Thieltges and Buschbaum, 2007; Decottignies et al., 2007a,b; Frésard and Boncoeur, 2006; Blanchard, 2009). These factors have contributed to large changes in foreign ecosystems, with significant impacts on local shell fisheries and fish populations (de Montaudouin et al., 1999; de Montaudouin and Sauriau, 1999; Thouzeau et al., 2000; Valett et al., 2001; Grall and Hall-Spencer, 2003; Thieltges, 2005a, Thieltges et al., 2006; Frésard and 
Boncoeur, 2006; Martin et al., 2007; Moulin et al., 2007; Reise and van Beusekom, 2008; Molnar, et al., 2008).

On the other hand, the slipper snail is now showing up in restaurants in France, Japan and Spain, having been harvested from those areas in which they have invaded (Clozel, 2014). Diners there are not the first to try these shellfish, as slipper snails have been consumed by people of the Azores and by members of the Portuguese community that settled in America along the Atlantic coast, including in New England, where they refer to them as "sweet meats" or "Lappas" after the limpets consumed in Portugal. These snails have a high nutritional content (Dagorn et al., 2014) and are flavorful (Mahaney et al., 2007). In France, Crepidula is touted as a culinary delicacy, where they are called "Berlingot des mers", for "pastries" or "candies of the sea" (see Fig 1H; Clozel, 2014). A better understanding of the molecular underpinning of embryonic and larval biology would be useful both for controlling and raising these snails.

\section{Insights into the cellular and molecular basis of Crepidula development}

The embryos of Crepidula are well-suited for studies on developmental biology, particularly at the cell and molecular levels (Henry et al., 2006, 2010a-d; Henry and Perry, 2008). The cell lineage has been well characterized (Hejnol et al., 1997; Lyons et al., 2012, 2015). Precise cell lineage ablation can be accomplished either by hand or using a laser (Lyons et al., 2012). One can readily perform cell/molecular functional studies, as embryonic cells are easy to inject (Henry et al., 2010d; Lyons et al., 2015), and one can thus introduce synthetic RNAs encoding various proteins and dominant negatives, or morpholino oligonucleotides, for gain- and loss-offunction studies (Henry et al., 2010d; Lyons et al., 2015). At least four EST data sets are available, covering a wide range of developmental stages to identify genes of interest (Henry et al., 2010c; Perry et al., 2015). Such studies have revealed a great deal about fundamental mechanisms that regulate development.

For example, classically, embryos with stereotyped cell lineages, such as spiralians, were assumed to specify cell fates by reliance on asymmetrically localized, cell-autonomous determinants. In C. fornicata, like its close relative Ilyanassa obsoleta (Lambert and Nagy, 2002), certain mRNAs are asymmetrically localized to specific cells, by virtue of their transient association with the centrosome and cell cortex (Henry et al., 2010c). However, detailed experiments using direct cell lineage tracing, experimental embryology, and investigations of the molecular underpinnings of development, have revealed that spiralians also employ inductive signals to specify cell fates and axial properties (Henry, 2014). Experiments have shown that the dorso-ventral axis is specified by inductive interactions from a key organizer in spiralians that arises from the $D$ (dorsal) cell quadrant; most typically it is the 3D macromere and/or its daughter the $4 d$ micromere that serves as the organizer (Fig. 3D-I, Henry, 2014). By removing specific cells one can assess the precise cellular and chronological basis of $D$ quadrant specification, as well as subsequent organizer signaling. In equal-cleaving spiralians, such as Crepidula, any one of the third quartet macromeres can be specified to become 3D, which occurs soon after the birth of the third quartet of micromeres (3a-3d) at the 20-cell stage (Henry et al., 2006; see Fig. 3D,G). 3D specification involves contacts with progeny of the first quartet (1q) micromeres (Fig 3F-G). Subsequently, the 3D macromere divides to form its daughter, 4d cell, at the 25-cell stage (Fig 3E, H). Once born, 4d serves to quickly signal the adjacent micromeres (Fig 3I). In C. fornicata, removal of the tiny polar lobe, a cytoplasmic protrusion inherited by the future D blastomere at the four-cell stage, leads to embryos with supernumerary D quadrant cells (i.e., "twins" or "triplets", Henry and Perry, 2008). Therefore, contents of the polar lobe are not essential to forming the $D$ quadrant, but instead bias selection of only one $D$ quadrant (Fig 3F-G). This may involve lateral inhibition to the three adjacent quadrants, though the molecular nature of those signals is not understood (Fig 3G). These data support a more 
complicated, multistep model of D quadrant specification and organizer activity, which involves both asymmetrically localized factors, and induction, than had been previously understood (Henry, 2014, Fig. 3F-I).

Studies are beginning to reveal the signaling cascades that regulate cell fate specification in Crepidula. MAPK signaling has been shown to be responsible for the specification of the D quadrant macromere 3D in both Crepidula and Ilyanassa (Lambert and Nagy, 2001, 2003; Henry and Perry, 2008), but not for 3D or 4d organizer activity per se. Other investigations reveal that gastrulation as well as the ultimate differentiation of endomesodermal fates derived from 4d in Crepidula, rely on active $\beta$-catenin signaling (Henry, et al., 2010d, unpublished data), which is consistent with the widely conserved role of $\beta$-catenin signaling in endomesoderm specification (Henry et al., 2008, 2010a).

\section{What have Crepidula cell lineage studies taught us?}

Modern cell lineage studies have used direct labeling of individual cells with fluorescent lineage tracers to construct detailed fate maps in slipper snails (Hejnol et al. 2007; Lyons et al. 2012; Lyons et al. 2015). For example, a recent study of the sublineages of the $4 \mathrm{~d}$ cell, which was known to be the progenitor of the bi-potential endomesoderm germ layer, revealed the exact origin of distinct tissues including hindgut, heart, muscles, larval kidney complex, and the primordial germ cells (Lyons et al., 2012). Characteristic of many spiralians, after its formation, $4 \mathrm{~d}$ divides to form the paired left and right teloblasts that generate both endoderm and mesoderm (endomesoderm). Fate mapping studies revealed that specific endodermal and mesodermal fates are segregated over a much greater number of teloblast divisions than had been previously known. Ablation experiments of those daughter cells showed that cell fates are established at birth, and no other cells can regulate to replace the missing tissues. These data suggest that the teloblasts have some mechanism to "count" cell divisions and perhaps segregate specific determinants to daughter cells with particular birth orders. A similar phenomenon has been demonstrated in the teloblasts of the annelid leech (Martindale and Shankland, 1990), but the underlying molecular mechanisms in both groups remain unknown.

Lineage tracing studies were also able to answer long-standing questions about gastrulation in the spiralians, including which lineages give rise to the mouth and anus, and the cell behaviors involved (Hejnol and Martindale, 2009, Lyons and Henry 2014). In Crepidula, gastrulation proceeds by epiboly, and the cells that contribute to the lip of the blastopore have been followed, including the progeny of the $2^{\text {nd }}$ and $3^{\text {rd }}$ quartet of micromeres (Fig 4A-E, Lyons et al., 2015). This study redefined the blastopore lip as the boundary between ectoderm and mesoderm/endomesoderm (Lyons et al., 2015), and showed that $C$. fornicata is a bona fide protostome (i.e., the cavity that leads to the embryonic gut or archenteron becomes the opening to the mouth, see also Chan and Lambert, 2014). This study also firmly established that the anus (derived from the $2 \mathrm{~d}$ lineage) forms at a site separate from the blastopore, which challenges certain evolutionary hypotheses, including the amphistomy hypothesis (Arendt and Nübler-Jung, 1997; Arendt, 2004; Lyons et al., 2015). The amphistomy hypothesis posits that protostomes and deuterostomes arose from an amphistomous ancestor in which both the mouth and the anus arose from the blastopore. Though some might interpret the events taking place in Crepidula to support the amphistomy hypothesis (as described by Arendt and Nübler-Jung, 1997; Arendt, 2004), we argue there is a lack of direct evidence to support that proposed series of events (Lyons et al., 2015). Unlike the mouth, the anus does not form from a persistent opening of the posterior blastopore in Crepidula. Although the anus is derived from progeny of $2 \mathrm{~d}$, only a few derivatives of this expansive clone initially lie along the posterior edge of the animal cap of ectoderm (e.g., 2d122 and 2d22, see Conklin, 1897) and those cells are displaced from the blastopore lip prior to the formation of the archenteron (Lyons et al., 2015). The 
opening of the anus actually forms several days later, presumably under the influence of inductive interactions with the terminal hindgut endoderm (Lyons et al., 2012, 2014, 2015).

\section{Studies of developmental dynamics}

C. fornicata embryos develop slowly and express fluorescently tagged proteins from injected mRNA, making them excellent material for live imaging (Fig 4C-E, K-O, Lyons et al., 2015). The combination of global expression of nuclear and cytoskeletal biosensors with fluorescent lineage tracers in specific cell lineages revealed the unique gastrulation behaviors of different cells. The $4 d$-derived endomesodermal clone is internalized passively, initially by the expansion of the ectodermal cap (Fig 4K), and later by the closure of the posterior lip of the blastopore. This latter process occurs by a posterior-to-anterior zippering of the $3 d^{2}$ and $3 c^{2}$ sublineages starting at the posterior lip of the blastopore (Fig 4F-J), and represents a form of convergent-extension. This morphogenetic process is likely modified in various spiralian groups, giving rise to the great variation of gastrulation modes in this clade (Arendt, 2004; Hejnol and Martindale, 2009, Lyons and Henry 2014). A different form of convergent-extension involving another cell lineage, the ventral trunk neuroectoderm, has been described from later stages of development in the annelid Platyneries (Steinmetz et al., 2007).

In contrast to the $3 d^{2}$ and $3 c^{2}$ sublineages in $C$. fornicata, cells along the anterior edge of the blastopore lip $\left(3 \mathrm{a}^{2}\right.$ and $\left.3 \mathrm{~b}^{2}\right)$ give rise to a second population of mesoderm derived from ectodermal precursors (called "ectomesoderm") (Lyons et al. 2015). These ectomesodermal progeny undergo an epithelial-mesenchymal transition (EMT), and extend filopodia and lamellipodia as they pass deep inside the embryo to migrate away from their site of internalization (Fig 4M-O). Imaging studies also suggest that the paired $2 \mathrm{~m}^{2.2}$ sublineages of endomesodermal $4 \mathrm{~d}$ cell gives rise to the germline. By labeling the actin cytoskeleton one can observe the primordial germ cells' dynamic behaviors to form long filopodia and lamellipodia that are presumably associated with directed migration towards the endoderm and future gonads (Lyons et al., 2012).

\section{Future directions}

A reliable and robust method for perturbing gene function during embryonic, larval, and adult stages is required to gain a mechanistic understanding of Crepidula biology. Both morpholino oligonucleotides, and dominant negative constructs, have been used successfully in the past (Henry et al., 2010 a,b; unpublished observations), but these methods have limited effectiveness at later stages. This impediment can be overcome through genome editing using CRISPR/Cas9 technology, which has recently been demonstrated in C. fornicata, where mCherry was coupled to the endogenous $\beta$-catenin gene (Fig. 5A-C, Perry and Henry, 2015). This permitted long-term observation of $\beta$-catenin expression, and represents the first demonstration of CRISPR/Cas9-mediated transgenesis in any member of the superphylum Spiralia. CRISPR/Cas9 technology provides a tool for both knocking genes out to assess gene function in the F0 generation, and for making stable transgenic lines of mutant snails or knock-in snail lines carrying various reporters. The only remaining hurdle is the lack of a sequenced genome. With preliminary estimates placing the $C$. fornicata genome at around 2.6pg (Paola Pierossi, Gregory Lab, Univ. of Guelph, personal communication), it should not be long before it is sequenced.

Perturbing gene function will permit the construction of gene regulatory networks (GRNs) to understand cell fate specification and morphogenesis. For example, one open question is the evolutionary relatedness of spiralian ectomesoderm and endomesoderm (Boyer et al., 1996; Lyons and Henry, 2014; Perry et al., 2015). Endomesoderm is argued to be an ancient bipotential tissue type shared by metazoans, and a conserved gene regulatory network (GRN) 
controls specification of endomesodermal territories in deuterostomes (Davidson et al., 2002a,b; Oliveri and Davidson, 2004; Smith and Davidson, 2008; Croce and McClay, 2010; Croce et al., 2011; Peter and Davidson, 2011; Solnica-Krezel and Sepich, 2012), ecdysozoans (Maduro, 2006; Gorfinkiel et al., 2011) and cnidarians (Röttinger et al., 2012). The ectomesoderm cell population may represent a novel innovation in the Spiralia (Boyer et al., 1996; Lyons and Henry, 2014; Chan and Lambert, 2014; Henry, 2014). A recent comparison of transcription factors expressed in $C$. fornicata ectomesoderm versus endomesoderm revealed that while many regulatory factors are expressed in both tissues, others are uniquely expressed in one or the other. For example, the genes snail2 and twist are expressed only in ectomesoderm, which may reflect their EMT behavior during gastrulation (Perry et al., 2015). Systems-level GRN analysis can uncover what upstream regulatory inputs regulate differential expression between ectomesoderm and endomesoderm, and whether removing particular genes like snail2 and twist block EMT. These types of data are necessary for making evolutionary inferences about the origins of novel cell types like the ectomesoderm.

The origins of the somatic gonad and the molecular underpinning of sex determination are wide open questions as well. For these studies, a direct developing species, such as $C$. atrasolea, will be useful, as their egg-to-egg generation time (6 months) is significantly faster than that in C. fornicata (well over a year, Henry and Lyons, unpublished observations; Rachel Collin, personal communications). Crepidula species, such as $C$. atrasolea, are easy to rear through successive generations in closed aquaria (Fig 1B, D-G, Henry et al., 2010; Pires, 2014; and our unpublished data). Another fruitful area for future research is comparisons of indirect versus direct development. The ability to compare species with different life history strategies, using a shared stereotyped cell lineage, will allow fine-grain comparisons of differences in morphology (e.g., Lyons et al., 2012). Modes of gastrulation (e.g., invagination vs. epiboly) are often tied to egg size (small vs. large eggs) and life history strategies (indirect-larval vs. direct development, Lyons and Henry, 2014). The wide range of developmental modes in the Crepidula genus offers future avenues for understanding how gastrulation and germ layer specification (e.g., ectomesoderm, which contributes largely to larval structures) may have changed over the course of these developmental transitions (Lyons and Henry, 2014). Ultimately, information gained from developmental studies might be employed in an effort to both rear these snails as a source of food as well as to control invasive populations of Crepidula in the wild.

\section{Acknowledgements:}

The authors acknowledge the invaluable support of the National Science Foundation NSF, and the MBL Embryology course. JQH is supported by NSF grant IOS-1558061. DCL thanks D.R. McClay for his support.

\section{References:}

-Arendt, D. (2004) Comparative aspects of gastrulation. In Gastrulation: from cells to embryo. C.D. Stern, ed. (New York: Cold Spring Harbor Laboratory Press), pp. 679-693. An interesting review of gastrulation modes in the metazoans.

•-Arendt, D., and Nübler-Jung, K. (1997) Dorsal or ventral: similarities in fate maps and gastrulation patterns in annelids, arthropods and chordates. Mech. Dev. 61:7-21 This paper includes a modern definition of amphistomy and scenarios for its modification for the origin of deuterostomy and protostomy.

Barnes, R.S.K., Coughlan, J. and Holmes, N.J. 1973. A preliminary survey of the macroscopic 
bottom fauna of the Solent, with particular reference to Crepidula fornicata and Ostrea edulis. Proceedings of the Malacological Society of London 40: 253-275.

Beninger, P.G., Decottignies, P., Guiheneuf, F., Barillé, L. and Rincé, Y. 2007. Comparison of particle processing by two introduced suspension feeders: selection in Crepidula fornicata and Crassostrea gigas. Marine Ecology Progress Series 334: 165-177.

••Blanchard, M. 1997. Spread of the slipper limpet Crepidula fornicata (L. 1758) in Europe. Current state and consequences. Scientia Marina 61, Supplement 2: 109-118. This is a thorough synopsis describing the extent and impact of Crepidula invasions.

Blanchard, M. 2009. Recent expansion of the slipper limpet population (Crepidula fornicata) in the Bay of Mont-Saint-Michel (Western Channel, France). Aquatic Living Resources 22: 11-19.

Blanchard, M., Pechenik, J.A., Giudicelli, E., Connan, J.-P. and Robert, R. 2008. Competition for food in the larvae of two marine molluscs, Crepidula fornicata and Crassostrea gigas. Aquatic Living Resources 21: 197-205.

••Boyer B.C., Henry J.Q., Martindale M.Q. (1996) Dual origins of mesoderm in a basal spiralian: cell lineage analyses in the polyclad turbellarian Hoploplana inquilina. Dev. Biol. 179: 329-338. This study describes the highly conserved nature of the spiral cleavage program and reveals the presence of both ecto- and endomesoderm in a more basal representative of the Spiralia

•-Cahill AE, Juman AR, Pellman-Isaacs A, Bruno WT. (2015). Physical and Chemical Interactions with Conspecifics Mediate Sex Change in a Protandrous Gastropod Crepidula fornicata. Biol Bull. 229(3):276-81. This paper provides experimental evidence that the factor controlling sex change in $C$. fornicata is a contactmediated inhibitor associated with female conspecifics.

- Carrillo-Boltodana, A, and Collin, R. (2015). Crepidula Slipper Limpets Alter Sex Change in Response to Physical Contact with Conspecifics. Biol Bull, 229: 232-242. Like the study above, this one also established that physical contact is needed to mediate the cues that regulate sex change using another slipper limpet, Crepidula cf. marginalis.

• Chan, X. Y. and Lambert, J. D. (2014). Development of blastomere clones in the Ilyanassa embryo: transformation of the spiralian blastula into the larval body plan. Dev Genes Evol. 224: 159-174. This paper reports on a very careful modern cell lineage analyses in the mud snail llyanassa obsoleta. Its development is very similar to that of Crepidula.

Chauvaud, L., Jean, F., Ragueneau, O. and Thouzeau, G. 2000. Long-term variation of the Bay of brest ecosystem: benthic-pelagic coupling revisited. Marine Ecology Progress Series 200: 35-48.

Chippenfield, P.N.J. 1951. The breeding of Crepidula fornicata (L.) in the river Blackwater, Essex. Journal of the Marine Biological Association of the U.K. 30: 49-71.

-Clozel, L (2014). In France, a quest to convert a sea snail plague into a culinary pleasure. The 
New York Times. March 12, International Section, A11. This article describes some efforts to deal with the invasive nature of Crepidula fornicata and the commercial development of Crepidula fornicata as a source of food for humans.

-Coe, W.R. 1936. Sexual phases in Crepidula. Journal of Experimental Zoology 72: 455-477. This is a classic study describing changes associated with sex change in protandric Crepidula snails.

-Coe, W.R. 1938. Conditions influencing change of sex in mollusks of the genus Crepidula. Journal of Experimental Zoology 77: 401-424. This early study describes conditions that regulate sex change in Crepidula.

-Coe, W.R. 1953. Influences of association, isolation, and nutrition on the sexuality of snails of the genus Crepidula. Journal of Experimental Zoology 122: 5-19. This study further describes the role of external factors in regulating sex change in Crepidula.

${ }^{*}$ Collin, R. (2000a). Phylogeny of Crepidula plana (Gastropoda: Calyptraidae) cryptic species complex in North America. Can. J. Zool. 78: 1500-1514. This study employed molecular approaches to characterize populations of Crepidula in eastern North America and also described a direct developing species, C. atrasolea.

Collin, R. (2000b). Sex change, reproduction and development of Crepidula adunca and C. lingulata (Gastropoda: Calyptraeidae) The Veliger. 43: 24-33.

Collin, R. 2001. The effects of mode of development on phylogeography and population structure of North Atlantic Crepidula (Gastropoda: Clayptraeidae). Mol. Ecol. 10: 22492262.

-Collin, R. 2003a. Phylogenetic relationships among calyptraeid gastropods and their implications for the biogeography of speciation. Syst. Biol. 52: 618-640.

A comprehensive study of calyptraeid phylogeny, origin, and dispersal.

Collin, R. 2003b. The utility of morphological characters in gastropod phylogenetics: An example from the Calyptraeidae. Biol. J. Linn. Soc. 78: 541-593.

•Collin, R. 2003c. Worldwide patterns in mode of development in calyptraeid gastropods. Mar. Ecol. Prog. Ser. 247: 103-122. This study compiled data on developmental characters for numerous species of calyptraeid gastropods: to correlate various conditions with specific modes of development.

Collin, R. 2004. Phylogenetic effects, the loss of complex characters, and the evolution of development in calyptraeid gastropods. Evolution 58: 1488-1502.

- Collin, R. and R. Cipriani. 2003. Dollo's Law and the re-evolution of shell coiling. Proc. Roy. Soc., Ser. B. 270: 2551-2555. This study provides evidence for the re-evolution of coiling in calyptraeid snails, and shows that developmental features underlying coiling have not been lost during approximately 20-100 million years of an uncoiled evolutionary history.

Collin, R., P. Farrell and S. Cragg. 2009. Confirmation of the identification and establishment of the South American slipper limpet Crepipatella dilatata (Lamark 1822) (Caenogastropoda: Calyptraeidae) in Northern Spain. Aquatic Invasions 4: 377-380. 
Collin, R., M. McLellan, K. F. Gruber, and C. Bailey-Jourdain. 2005. Effects of conspecific associations on size at sex change in three species of calyptraeid gastropods. Mar. Ecol. Prog. Ser. 293: 89-97.

Collin, R. and Spangler, A. 2012. Impacts of Adelphophagic Development on Variation in Offspring Size, Duration of Development, and Temperature-Mediated Plasticity. Biological Bulletin 223 (3): 268-277.

Collin, R., M. Wonham, and K. R. Barr. 2006. Crepidula convexa Say 1822 (Caenogastropoda: Calyptraeidae) in Washington State, USA. Am. Malacol. Bull. 21: 113-116.

•-Conklin, EG. (1897). The embryology of Crepidula. J. Morphol. 13: 1-226. This represents the first complete description of development in Crepidula, and established the universal spiral cleavage nomenclature that is still used today. Along with other studies carried at that time, it uncovered the highly conserved nature of early development in spiralians that helped usher in the field of evolution and development.

•-Croce JC and McClay DR. (2010). Dynamics of Delta/Notch signaling on endomesoderm segregation in the sea urchin embryo. Development 137:83-91.

Shows that Delta signaling is necessary for mediating mesoderm fate and the segregation of endoderm and mesoderm in the sea urchin

-Croce JC, Range R, Wu SY, Miranda E, Lhomond G, Peng, JC, Lepage T and McClay DR. (2011). Wnt6 activates endoderm in the sea urchin gene regulatory network. Development 138: 3297-3306. Demonstrates that when vegetal cortex of the sea urchin egg is removed (which results in the loss of all endomesoderm), the addition of Wnt6 mRNA can rescue endoderm formation.

Dagorn F, Buzin F, Couzinet-Mossion A, Decottignies P, Viau M, Rabesaotra V, Barnathan G, Wielgosz-Collin G. (2014). Multiple beneficial lipids including lecithin detected in the edible invasive mollusk Crepidula fornicata from the French Northeastern Atlantic coast. Mar Drugs. ;12:6254-68.

•-Davidson EH, Rast JP, Oliveri P, Ransick A, Calestani C, Yuh CH, Minokawa T, Amore G., Hinman V, Arenas-Mena C, Otim O., Brown CT, Livi CB, Lee PY, Revilla R, Rust AG, Pan Zj, Schilistra MJ, Clarke PJ, Arnone MI, Rown L, Cameron RA, McClay, DR, Hood $L$ and Bolouri $H$. (2002a). A genomic regulatory network for development. Science 295:1669-1678. Early comprehensive analysis of the sea urchin endomesoderm GRN using perturbation and cis-regulatory analysis.

•-Davidson EH, Rast JP, Oliveri P, Ransick A, Calestani C, Yuh CH, Minokawa T, Amore G., Hinman V, Arenas-Mena C, Otim O., Brown CT, Livi CB, Lee PY, Revilla R, Rust AG, Pan Zj, Schilistra MJ, Clarke PJ, Arnone MI, Rown L, Cameron RA, McClay, DR, Hood $\mathrm{L}$ and Bolouri $\mathrm{H}$. (2002b). A provisional regulatory gene network for specification of endomesoderm in the sea urchin embryo. Dev Biol 246: 162-190. Detailed description of methods and logic of constructing the sea urchin endomesoderm GRN, focusing on $\mathbf{4 0}$ nodes, mostly transcription factors and signaling molecules.

Decottignies, P., Beninger, P.G., Rincé, Y., Robins, R.J. and Riera, P. 2007a. Exploitation of 
natural food sources by two sympatric, invasive suspension-feeders: Crassostrea gigas and Crepidula fornicata. Marine Ecology Progress Series 334: 179-192.

Decottignies, P., Beninger, P.G., Rincé, Y. and Riera, P. 2007b. Trophic interactions between two introduced suspension-feeders, Crepidula fornicate and Crassostrea gigas, are influenced by seasonal effects and qualitative selection capacity. Journal of Experimental Marine Biology and Ecology 342: 231-241.

Dommasnes, A. and Schram, T. 1973. Nytt funn av tøffelsnegl Crepidula fornicata L. i Norge. Fauna 26: 249-252.

Ehrhold, A., Blanchard, M., Auffret, J.-P. and Garlan, T. 1998. Conséquences de la prolifération de la crépidule (Crepidula fornicata) sur l'évolution sédimentaire de la baie du MontSaint-Michel (Manche, France). Comptes Rendue Académie des Sciences, Paris, Science de la terre et des planètes 327: 583-588.

Frésard, M. and Boncoeur, J. 2006. Costs and benefits of stock enhancement and biological invasion control: the case of the Bay of Brest scallop fishery. Aquatic Living Resources 19: 299-305.

Gaffney, P.M. and McGee, B. 1992. Multiple paternity in Crepidula fornicata (Linnaeus). Veliger 35(1): 12-15.

Gorfinkiel N, Schamberg S. and Blanchard GB. (2011). Integrative approaches to morphogenesis: lessons from dorsal closure. Genesis. 49:522-533.

Grall, J., and J.M. Hall-Spencer. 2003. Problems facing maerl conservation in Brittany. Aquatic Conservation: Marine and Freshwater Ecosystems 13: 55-64.

Hedeselskabet, 2003. Limfjordsovervågningen. Bundfaunamonitering Limfjorden 2003. Limfjordsovervågningen, c/o Viborg Amt, 120pp.

-Hejnol, A., and Martindale, M.Q. (2009) The mouth, the anus, and the blastopore- open questions about questionable openings. In: Animal Evolution. Genomes, Fossils, and Trees, M.J. Telford and D.T.J. Littlewood, eds. (Oxford: Oxford University Press), pp. 33-40. Comprehensive review of available data and descriptions of gastrulation modes in the metazoans, especially under-studied clades of bilaterians.

-Hejnol, A., Martindale, M. Q. and Henry J. Q. (2007). High resolution fate map of the gastropod snail Crepidula fornicata. Origins of ciliary bands, nervous and musculature elements. Developmental Biology 305: 63-76. First modern cell lineage analyses of Crepidula fornicata using fluorescent cell autonomous lineage tracers.

-Henry, J. J. and Perry, K. J. (2008). MAPK activation and the specification of the D quadrant in the gastropod mollusc Crepidula fornicata. Developmental Biology, 313: 181-195. This study revealed that MAPK activation plays a key role in the specification of the dorsal D quadrant but not in organizer activity, per se, in a modle spiralian.

-Henry, J. J., Perry, K. J., Fukui, L. and Alvi, N. (2010d). Differential Localization of mRNAs During Early Development in the Mollusc, Crepidula fornicata. Integrat. Compar. Biology 50: 720-733. As was shown for the mud snail, Ilyanassa obsoleta, this study showed that mRNAs are 
localized to specific cell lineages during early clevaage in Crepidula, in a process similar to that described for the mud snail llysanassa obsoleta.

•Henry, J. Q. (2014). Spiralian Model Systems. International J. of Dev. Biol. 58: 389-401. This review provides an overview of what has been learned using different spiralian model systems, including Crepidula.

••Henry, J. Q. Perry, K. J. and Martindale, M. Q. (2006). Cell specification and the role of the polar lobe in the gastropod mollusc, Crepidula fornicata. Developmental Biology. 297: 295-307. This study showed that the polar lobe of Crepidula fornicata does not play the same role as that found in many other species, where they are known to be essential for dorsal D quadrant specification, and ultimately organizer function.

••Henry, J. Q., Collin, R. and Perry, K. J. (2010a). The Slipper Snail, Crepidula: An Emerging Lophotrochozoan Model System. The Biological Bulletin. 218: 211-229). This review focusses on Crepidula as a useful model system for biological studies.

Henry, J. Q., Collin, R. and Perry, K. J. (2010b). Methods for Working with the Slipper snail, Crepidula: An Emerging Lophotrochozoan Model System. The Biological Bulletin. (On-line, Peer-reviewed companion to the paper listed above, see www.life.illinois.edu/henry/crepidula_methods.html, see also http://biogeodb.stri.si.edu/bioinformatics/dfm/metas/view/ 38301).

- Henry, J. Q. and Perry, K. J. and Martindale, M. Q. (2010c). $\beta$-catenin and early development in the gastropod, Crepidula fornicata Integrat. Compar. Biology 50: 707-719. This paper revealed a role of beta-catenin signal transduction in the development of the $4 \mathrm{~d}$ mesentoblast lineage, which is consistent with the conserved role of beta-catenin in endomesoderm development.

Hessland, I. 1951. Notes on Crepidula fornicata's further invasion in Europe. Arkiv för Zoologi 2(5): 525528.

Hoagland, K.E. 1977. Systematic review of fossil and recent Crepidula. Malacologia, 16: 363-420.

Hoagland, K. E. 1978. Protandry and the evolution of environmentally mediated sex change: a study of the Mollusca. Malacologia 17: 365-391.

Hoagland, K.E. 1984. Use of molecular genetics to distinguish species of the gastropod genus Crepidula (Prosobranchia: Calyptraeidae). Malacologia, 25: 607-628.

Hoagland KE, 1985. Genetic relationship between one British and several North American populations of Crepidula fornicata based on allozyme studies. J. Moll. Studies, 51:117-182.

Holm G (2006) Crepidula onyx G.B. Sowerby I, 1824 collected in puget Sound. The Dredgings 46(5): 3-4

Huang, Z.G., B. Morton, M. W. Yipp. 1983. Crepidula onyx introduced into and established in Hong Kong. Malacol. Rev. 16: 97-98.

Johnson, J.K. 1972. Effect of turbidity on the rate of filtration and growth of the slipper limpet, Crepidula fornicata Lamarck, 1799. Veliger 14(3): 315-320. 
Korringa, P. 1942. Crepidula fornicata's invasion in Europe. Basteria 7(1-2): 12-23.

Kocot, K. M., Cannon, J. T., Todt, C., Citarella, M. R. Kohn, A. B., Achim Meyer, A., Santos, S. R., Schander, C., Moroz, L. L., Lieb, B. and Halanych, K. M (2011). Phylogenomics reveals deep molluscan relationships. Nature 477: 452-456.

- Lambert, J. D. and Nagy, L. M. (2001). MAPK signaling by the D quadrant embryonic organizer of the mollusc llyanassa obsoleta. Development 128: 45-56. First demonstration of a molecular signaling pathway involved in organizer function in spiralians.

•-Lambert, J. D. and Nagy, L. M. (2002). Asymmetric inheritance of centrosomally localized mRNAs during embryonic cleavages. Nature 420,682-686. Shows how developmentally relevant transcripts (e.g. dpp) undergo a cycle of association with the cell cortex and centrosome, revealving a cellular mechanism for segregation into certain cells in the embryo during cleavage stages.

Lambert, JD, and Nagy, LM. (2003). The MAPK cascade in equally cleaving spiralian embryos. Dev Biol. 263: 231-241.

Le Pape, O., Guérault, D. and Désaunay, Y. 2004. Effect of an invasive mollusc, American slipper limpet Crepidula fornicata, on habitat suitability for juvenile common sole Solea solea in the Bay of Biscay. Marine Ecology Progress Series 277: 107-115.

-Lesoway, M.P., Abouheif, E. and R. Collin. 2014. The development of viable and nutritive embryos in the direct developing gastropod Crepidula navicella. International Journal of Developmental Biology. 58: 601-611. This recent paper describes an interesting mode of development found in certain species of Calyptraeidae snails.

Loomis, S.H. and van Nieuwenhuyze, W. 1985. Sediment correlates to density of Crepidula fornicata Linnaeus in the Pataguanset River, Connecticut. The Veliger 27(3): 266-272.

Louis M. 1963, The slipper limpet population (Crepidula fornicata L.) in France. Science et Pêche (0036-8350) (ISTPM), Vol. 121, P. 1-6

-Lyons D. C. and Henry, J. Q. (2014). The Ins and Outs of Gastrulation in the Spiralia. International J. of Dev. Biol. 58: 413-428. This is an extensive review of gastrulation processes and mechanisms in various members of the Spiralia.

•-Lyons, D. C. Perry, K. J., Lesoway, M. P. and Henry, J. Q. (2012). Cleavage pattern and fate map of the mesentoblast, $4 \mathrm{~d}$, in the gastropod Crepidula: A hallmark of spiralian development. EvoDevo 3: 21. This paper reports on the cleavage pattern and cell lineage of the mesentoblast (4d) in C. fornicata and C. convexa. This is the first thorough lineage analyses of this cell in any spiralian model system. Modern cell lineage tracers were used to determine the origins of specific endodermal and mesodermal fates and the two primordial germ cells that arise as daughters of the paired teloblasts.

••Lyons, D. C., Perry, K. J. and Henry, J. Q. (2015). Gastrulation in the slipper snail Crepidula fornicata: germ layer formation, morphogenesis, and the fate of the blastopore in a model spiralian "protostome" EvoDevo 6:24. This paper characterized the process of gastrulation in a model lophotrochozoan, Crepidula fornicata, where gastrulation occurs by epiboly. Observations revealed that the posterior blastopore lip closes by convergent extension. These findings have important ramifications for hypotheses regarding the evolution of 
protostomes and dueterostomes, including the amphystomy hypothesis. This paper also followed the behavior of ectomesodermal cells that undergo EMT.

-Maduro MF. (2006). Endomesoderm specification in Caenorhabditis elegans and other nematodes. Bioessays 28:1010-1022. Review of the endomesoderm GRN in C. elegans with discussion of how the network might be modified over evolution by comparison with other nematode species.

Mahaney, LA, Pereira, F and McKenzie, W. B. (2007). Crepidula fornicata: A nuisance or an ethnic speciality. Northeast Decision Sciences Institute Conference Proceedings, Roger Williams University.

Martin, S., Thouzeau, G., Richard, M., Chauvaud, L., Jean, F. and Clavier, J. 2007. Benthic community respiration in areas impacted by the invasive mollusk Crepidula fornicata. Marine Ecology Progress Series 347: 51-60.

Martindale, M. Q. and Shankland, M. (1990). Intrinsic segmental identity of segmental founder cells in the leech embryo. Nature, 347: 672-674.

Minchin, D. (2007). Rapid coastal survey for targeted alien species associated with floating pontoons in Ireland. Aquatic Invasions. 2: 63-70.

Minchin, D., McGrath, D., Duggan, C.B. (1995). The slipper limpet Crepidula fornicata (L.) in Irish waters with a review of its occurrence in the north-east Atlantic. Journal of Conchcology, London 35(5): 297-301.

Molnar, J. L., Gamboa, R. L., Revenga, C. and Spalding, M. C. 2008. "Assessing the global threat of invasive species to marine biodiversity." Frontiers in Ecology and the Environment. 6 (9), pp. 485-492.

Montaudouin, X. de, Audemard, C. and Labourg, P.-J. 1999. Does the slipper limpet (Crepidula fornicata, L.) impair oyster growth and zoobenthos biodiversity? A revisited hypothesis. Journal of Experimental Marine Biology and Ecology 235: 105-124.

Montaudouin, X. de and Sauriau, P.G. 1999. The proliferating Gastropoda Crepidula fornicata may stimulate macrozoobenthic diversity. Journal of the Marine Biological Association of the U.K. 79: 1069-1077.

Moulin, F.Y., Guizen, K., Thouzeau, G., Chapalain, G., Mülleners, K. and Bourg, C. 2007. Impact of an invasive species, Crepidula fornicata, on the hydrodynamics and transport properties of the benthic boundary layer. Aquatic Living Resources 20: 15-31.

Nehls, G., Diederich, S., Thieltges, D.W. and Strasser, M. 2006. Wadden Sea mussel beds invaded by oysters and slipper limpets: competition or climate control? Helgoland Marine Research 60: 135-143.

Newell, R.C. and Kofoed, L.H. 1977. The energetics of suspension-feeding in the gastropod Crepidula fornicata L. Journal of the Marine Biological Association of the U.K. 57: 161-180.

Osca D, Templado J, Zardoya R. (2015). Caenogastropod mitogenomics. Mol Phylogenet Evol. 93 : 118-28. 
Oliveri, P. and Davidson EH. (2004). Gene regulatory network analysis in sea urchin embryos. Methods Cell Biol 74:775-794.

Orton, J.H. 1912a. An account of the natural history of the slipper-limpet (Crepidula fornicata), with some remarks on its occurrence on the oyster grounds on the Essex coast. Journal of the Marine Biological Association of the U.K. 9: 437-443.

Padilla DK, McCann MJ, Glenn MM, Hooks AP, Shumway SE. (2014). Effect of food on metamorphic competence in the model system Crepidula fornicata. Biol Bull. 227(3):242-51.

Pechenik, J.A., K. Hammer, and C. Weise. 1996a. The effect of starvation on acquisition of competence and postmetamorphic performance in the marine prosobranch gastropod Crepidula fornicata (L.). J. Exp. Mar. Biol. Ecol. 199: 137-152.

Pechenik, J.A., S. Estrella, and K. Hammer. 1996b. Food limitation stimulates metamorphosis and alters postmetamorphic growth rate in the marine prosobranch gastropod Crepidula fornicata. Mar. Biol. 127: 267-275.

-Pechenik, J. A., D. E. Cochrane, W. Li, E. T. West, A. Pires, and M. Leppo. 2007. Nitric oxide inhibits metamorphosis in larvae of Crepidula fornicata, the slippershell snail. Biol. Bull. 213: 160-171. This study revealed that nitric oxide acts as an endogenous inhibitor of metamorphosis and that decreased levels of nitric oxide permit metamorphosis in Crepidula fornicata.

Pires A. (2014). Artificial seawater culture of the gastropod Crepidula fornicata for studies of larval settlement and metamorphosis. Methods Mol Biol. 1128:35-44.

••Perry, K. J and Henry, J. Q. (2014). CRISPR/Cas9-mediated genome modification in the mollusc Crepidula fornicata. Genesis 53: 237-244. This is the first study to demonstrate successful modification of an endogenous locus in any lophotrochozoan using CRISPR/Cas9.

-Perry, K. J., Lyons, D. C., Truchado-Garcia, M. Fischer, A., Helfrich, L., Johansson, K., Diamond, J., Grande, C., and Henry, J. Q. (2015). Deployment of regulatory genes during gastrulation and germ layer formation in a model spiralian, Crepidula fornicata. Developmental Dynamics vol. 244, (10): 1215-1248. This study uncovered shared expression of genes in both ecto- and endomesoderm, suggesting that components of the conserved endomesoderm program were either co-opted for ectomesoderm formation or that ecto- and endomesoderm are derived from a common mesodermal precursor that became subdivided into distinct domains during evolution.

-Peter IS and Davidson EH. (2011). A gene regulatory network controlling the embryonic specification of endoderm. Nature. 474:635-9. Describes the construction of a GRN for endoderm specification including subnetworks for various sublineages.

Rayment, W. 2008. Crepidula fornicata. Slipper limpet. Marine Life Information Network: Biology and Sensitivity Key Information Sub-programme. Plymouth: Marine Biological Association of the United Kingdom. 
Richard, J., Huet, M., Thouzeau, G. and Paulet, Y.-M. 2006. Reproduction of the invasive slipper limpet, Crepidula fornicata, in the Bay of Brest, France. Marine Biology 149: 789801.

Riera, P. 2007. Trophic subsidies of Crassostrea gigas, Mytilus edulis and Crepidula fornicata in the Bay of Mont Saint Michel (France): A $\delta 13 \mathrm{C}$ and $\delta 15 \mathrm{~N}$ investigation. Estuarine, Coastal and Shelf Science 72: 33-41.

Reise, K., van Beusekom, J.E.E. 2008. Interactive effects of global and regional change on a coastal ecosystem. Helgoland Marine Research 62: 85-91.

••Röttinger E, Dahlin P and Martindale MQ. (2012). A framework for the establishment of a cnidarian gene regulatory network for "endomesoderm" specification: the inputs of $\beta$ catenin/TCF signaling. PLoS Genet. 8(12):e1003164. First GRN, based on direct gene perturbation, for endoderm specification in cnidarians.

Sauriau, P.G., Pichocki-Seyfried, C., Walker, P., De Montauduin, A., Pascual, A., Deslou, M. (1998). Crepidula fornicata L. (Mollusca, Gastropoda) in the Marennes-Oleron Bay : side-scan sonar mapping of subtidal and stock assessment. Oceanologica Acta 21: 353-362.

Sigwart, JH. D. and Lindberg, D. R. (2014). Consensus and Confusion in Molluscan Trees: Evaluating Morphological and Molecular Phylogenies. Systematic Biology 64: 384-395.

Smith J and Davidson EH. (2008). Gene regulatory network subcircuit controlling a dynamic spatial pattern of signaling in the sea urchin embryo. Proc Natl Acad Sci U S A 105:20089-20094.

••Solnica-Krezel L and Sepich DS. (2012). Gastrulation: Making and Shaping Germ Layers. Annual Review of Cell and Dev. Biology. 28:687. Thorough review of gastrulation processes and mechanisms.

Sjøtun, K. 1997. A new observation of Crepidula fornicata (Prosobranchia, Calyptraeidae) in Western Norway. Sarsia 82(3): 275-276.

Spärck, R. 1935. On the occurrence of Crepidula fornicata (L.) in the Limfjord. Reports from the Danish Biological Station 40: 43-44.

Spärck, R. 1950. On the distribution of the slipper-limpet (Crepidula fornicata) in Danish waters. Reports from the Danish Biological Station 52: 48-50.

Steinmetz PR, Zelada-Gonzáles F, Burgtorf C, Wittbrodt J, Arendt D. (2007). Polychaete trunk neuroectoderm converges and extends by mediolateral cell intercalation. Proc Natl Acad Sci U S A. 104: 2727-2732.

Struck TH, Wey-Fabrizius AR, Golombek A, Hering L, Weigert A, Bleidorn C, Klebow S, lakovenko N, Hausdorf B, Petersen M, Kück P, Herlyn H, Hankeln T. (2014). Platyzoan paraphyly based on phylogenomic data supports a non-coelomate ancestry of Spiralia. Mol Biol Evol. [Epub ahead of print]

-Taris, N., T. Comtet, and F. Viard. 2009. Inhibitory function of nitric oxide on the onset of metamorphosis in competent larvae of Crepidula fornicata: A transcriptional perspective. 
Mar. Genomics, 2: 161-167. This study provides evidence for the role of nitric oxide signaling in the regulation of metamorphosis in Crepidula fornicata.

Thieltges, D.W. 2005a. Benefit from an invader: American slipper limpet Crepidula fornicata reduces star fish predation on basibiont European mussels. Hydrobiologia 541: 241-244.

Thieltges, D.W. 2005b. Impact of an invader: epizootic American slipper limpet Crepidula fornicata reduces survival and growth in European mussels. Marine Ecology Progress Series 286: 13-19.

Thieltges, D.W. and Buschbaum, C. 2007. Mechanism of an epibiont burden: Crepidula fornicata increases byssus thread production by Mytilus edulis. Journal of Molluscan Studies 73(1): 75-77.

Thieltges, D.W., Strasser, M. and Reise, K. 2003. The American slipper limpet Crepidula fornicata (L.) in the northern Wadden Sea 70 years after its introduction. Helgoland Marine Research 57: 27-33.

-Thieltges, D.W., Strasser, M. and Reise, K. 2006. How bad are invaders in coastal waters? The case of the American slipper limpet Crepidula fornicata in western Europe. Biological Invasions 8: 1673-1680. This paper considers both negative and the positive effects of Crepidula colinization, pointing out that some studies have failed to demonstrate negative impacts from invasive populations of these snails.

Thouzeau, G., Chavaud, L., Grall, J. and Guérin, L. 2000. Rôle des interactions biotiques sur le devenir du pré-recrutement et la croissance de Pecten maximus (L.) en rade de Brest. Comptes Rendue Académie des Sciences, Paris, Sciences de la vie 323: 815-825.

Vallet, C., Dauvin, J.-C., Hamon, D. and Dupuy, C. 2001. Effect of introduced common slipper shell on the suprabenthic biodiversity of the subtidal communities in the Bay of Saint-Brieuc. Conservation Biology 15(6): 1686-1690.

Viard F., 2010. Focus on the slipper limpet Crepidula fornicata (Linnaeus, 1758), a non-indigenous and successful mollusc in Europe. Cah. Biol. mar., 51 : 92-93.

Viard, F., Ellien, C. and Dupont, L. 2006. Dispersal ability and invasion success of Crepidula fornicata in a single gulf: insights from genetic markers and larval-dispersal model. Helgoland Marine Research 60: 144-152.

Walne, P.R. (1956). The biology and distribution of the slipper limpet Crepidula fornicata in Essex rivers with notes on the distribution of larger epi-benthic invertebrates. Fisheries Investigations London (2) 20 No 6: 1-52

Williams ST, Foster PG, Littlewood DT. (2014). The complete mitochondrial genome of a turbinid vetigastropod from MiSeq Illumina sequencing of genomic DNA and steps towards a resolved gastropod phylogeny. Gene. 533: 38-47.

\section{Figure Legends:}

Figure 1. A. two curved stacks of adult Crepidula fornicata. Large individuals are females while the smaller ones are males, as labeled. B. Adult $C$. atrasolea that have settled on a clam shell. Unlike C. fornicata, these animals do not form stacks. C. Indirect developing, planktonic, 
veliger larva of $C$. fornicata. Notice the large ciliated velum, which is eventually lost at metamorphosis. D. transparent egg sac containing four direct-developing (non-feeding) $C$. atrasolea. These have a greatly reduced velum, and hatch as crawl-away juvenile snails. Simple process for rearing $C$. atrasolea snails in the lab. C. juvenile snails (jv) being reared in small petri dishes. Once they reach sizes greater than $2 \mathrm{~mm}$ they are transferred to floated chambers with screened end caps $(F)$ where they continue to be fed commercial dead phytoplankton (Phytofeast). G. Close-up view of the culture chamber with one end cap removed. Notice the two larger gravid females (black arrowheads), surrounded by smaller males. H. Tasty salad appetizer of Crepidula sautéed in white wine, butter, garlic and saffron, served with a flavorful dressing, over a bed of mesclun and other vegetables, garnished with finger lime pulp. ft, foot; oc, ocelli; sh, shell; tn, tentacle; vl, velum. Scale bars equal $1 \mathrm{~cm}$ for $\mathrm{A}$ and $\mathrm{B}, 50 \mu \mathrm{m}$ for $\mathrm{C}$, and $\mathrm{D}, 1 \mathrm{~cm}$ for $\mathrm{F}$, and $\mathrm{G}$.

Figure 2. A. Phylogenetic relationships between various Lophotrochozoa/Spiralia. These phylogenetic relationships are somewhat unclear, and this phylogram is based on a recent consensus reached by several authorities (see review by Henry, 2014). This view does not take into account the findings of Struck et al. (2014), which would remove the Gnathozoa" or "Gnathifera" from the platyzoan clade, and make additional changes to the topology of this tree. Other enigmatic groups with uncertain relationships include the Acanthocephala (thought to be related to the Rotifera as Syndermata), the Myzostomida (thought to represent derived annelids), and the Mesozoa. B. One proposed phylogeny for the Mollusca (from Kocot et al., 2011). Phylogenetic relationships amongst the Mollusca are also highly contentious (see Sigwart and Lindberg, 2014; and Williams et al., 2014; Osca et al., 2015 for relationships within the Gastropoda). The various named clades are labeled for particular nodes. Phyla and classes that contain species exhibiting spiral cleavage are underlined in green. Figure modified after that of Henry (2014).

Figure 3. A-E. Animal pole views of spiral cleavage, showing birth of the successive micromere quartets within the four basic cell quadrants (termed A-D by convention). Dorsal (D quadrant) is down, ventral (B quadrant) is up. Micromere daughters are labeled with lower case letters. For instance the first quartet micromeres (generically called $1 \mathrm{q}$ cells) are named $1 \mathrm{a}, 1 \mathrm{~b}$, $1 \mathrm{c}$, and $1 \mathrm{~d}$. When those cells divide their animal-most daughters (collectively called the $1 \mathrm{q}^{1}$ cells) are named $1 \mathrm{a}^{1}, 1 \mathrm{~b}^{1}, 1 \mathrm{c}^{1}$, and $1 \mathrm{~d}^{1}$. The vegetal-most large macromeres are labeled with upper case letters (e.g., 1A. 1B. 1C. 1D). Ultimate germ layer fates for these cells are indicated, as shown in the color key (illustrations after Lyons and Henry, 2014). Darker colors signify the initial birth of particular micromere quartets. Grey = mother cells (e.g., macromeres) prior to the generation of all four of their micromere daughters. F-I. Model showing steps involved in D quadrant specification and 4d organizer activity in Crepidula (illustrations after Henry, 2014). Signaling interactions (factors, lines and arrows) implicated in some events are noted with corresponding colors. The molecular basis of some signaling interactions are undetermined (?).

Figure 4. A-B. Micromere specific clones of the blastopore (bp). Clones labeled, as colored. F$\mathrm{J}$. Process of gastrulation (epiboly) and blastopore constriction involving convergent-extension of $3 c^{2}$ and $3 d^{2}$ progeny (enclosed in the shaded boxes shown in $\mathrm{F}$ and $\mathrm{J}$ of the larger red and green fluorescently labeled $3 c$ and $3 d$ clones, as labeled). Location of the constricting blastopore (bp) is indicated by dotted lines. The blastopore ultimately gives rise to the mouth (protostomy). Anterior is towards the top of the figure. K clone of $4 \mathrm{~d}$ derived endomesoderm (red dil fluorescence) is seen underneath the advancing cap of ectoderm (green fluorescence). Animal pole is towards the top of the figure. L-O. Formation of ectomesoderm from $3 \mathrm{~b}$. Cells derived specifically from the $3 \mathrm{~b}^{2}$ subclone undergo EMT to form mesenchyme visualized by the wondering dil labeled progeny (red). For L-O the views are as marked in $\mathrm{O}$ (illustrations after 
Lyons et al., 2015). Embryonic cells outlined with Utrophin-GFP (green fluorescence) as an Factin binding biosensor, and nuclei labeled with Histone H2B-mCherry (red fluorescence) are seen in the embryos shown in $\mathrm{C}-\mathrm{E}$ and $\mathrm{K}-\mathrm{O}$, as indicated. Scale bar in $\mathrm{E}$ equals $50 \mu \mathrm{m}$.

Figure 5. Successful transgenic integration showing expression of $m$ Cherry-tagged $\beta$-catenin in $C$. fornicata embryos. (A) An embryo in the mid-stages of gastrulation showing mosaic expression of $\beta$-catenin-mCherry fluorescence in what appears to be a $4^{\text {th }}$ quartet macromere $(4 \mathrm{Q})$ and its daughter $(4 q)$ macromere daughters of the $D$-quadrant (ventral view). Some nuclear localization is seen in two of these cells (arrowheads). (B) Brightfield and corresponding fluorescence (C) inferior view of a 14-day old veliger larva. Expression is observed in cells of the right and left mid-gut glands, and in two other cells lying adjacent to the hindgut intestine, that could be the two primordial germ cells. Nuclear localization is seen in many of the endodermal cells. bp, blastopore; ft, foot; int, intestine; Img, left mid-gut gland; pgc, putative primordial germ cells; rmg, right mid-gut gland; sh, shell; vl, velar lobes. Scale bar in D

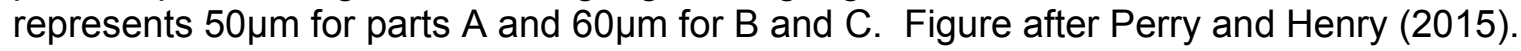




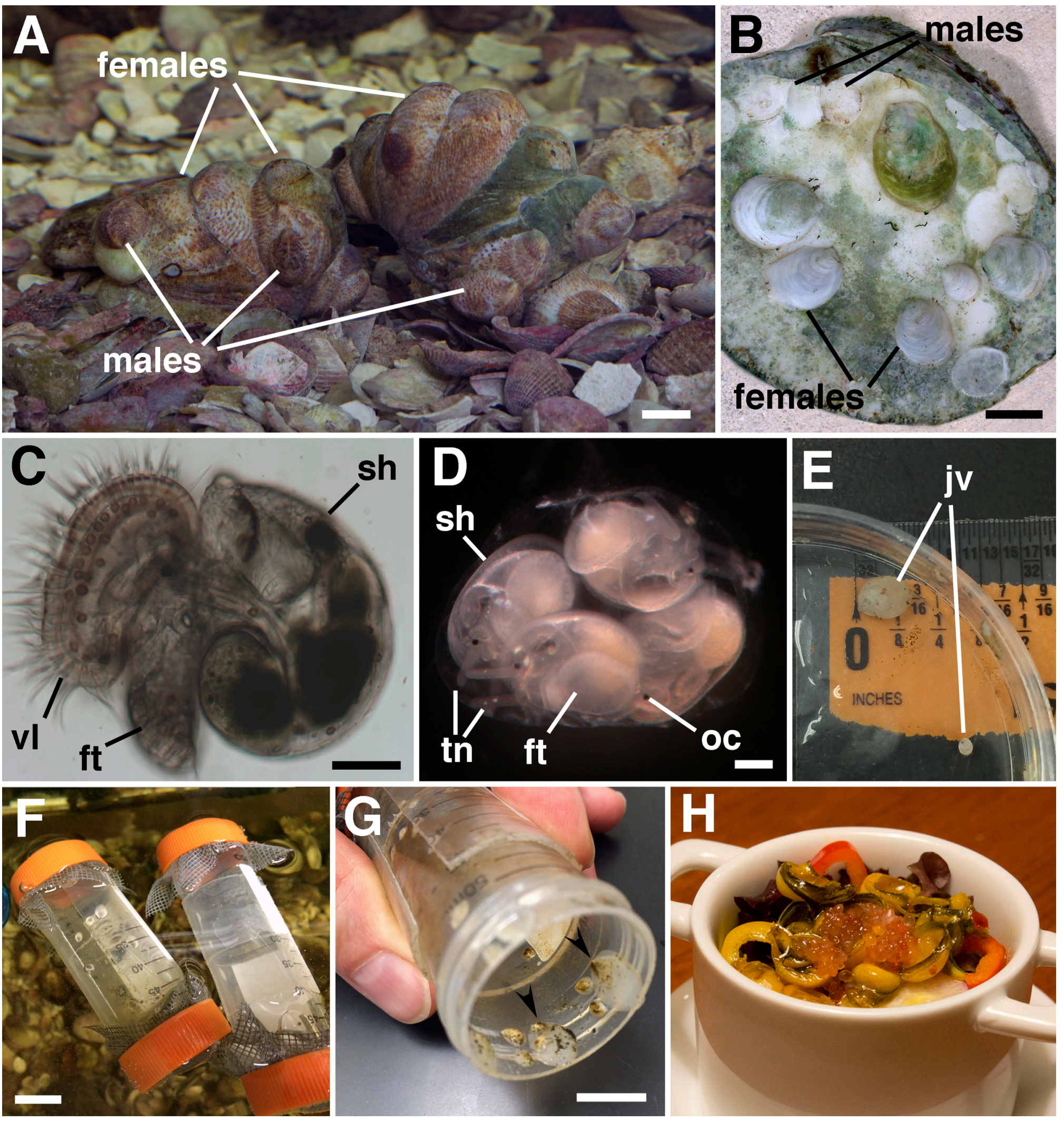



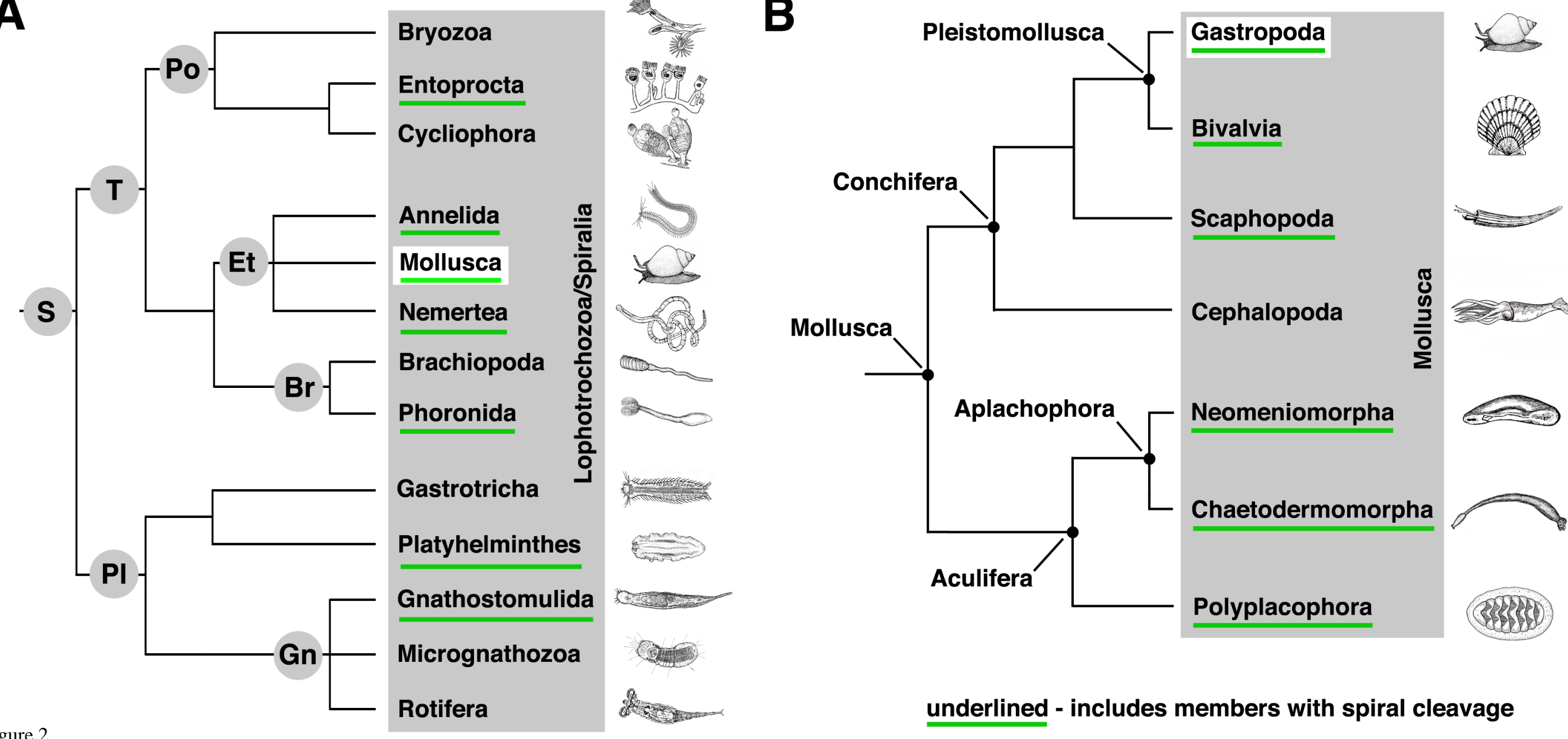

underlined - includes members with spiral cleavage 
figure 3

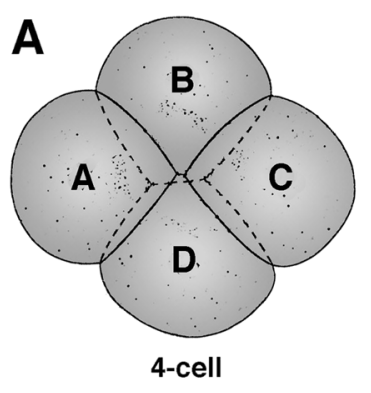

Ectoderm

F

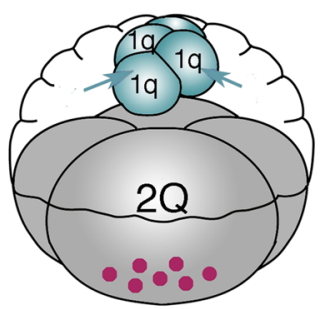

Priming first quartet (1q) Lobe factors bias $D$ mac MAPK, ?
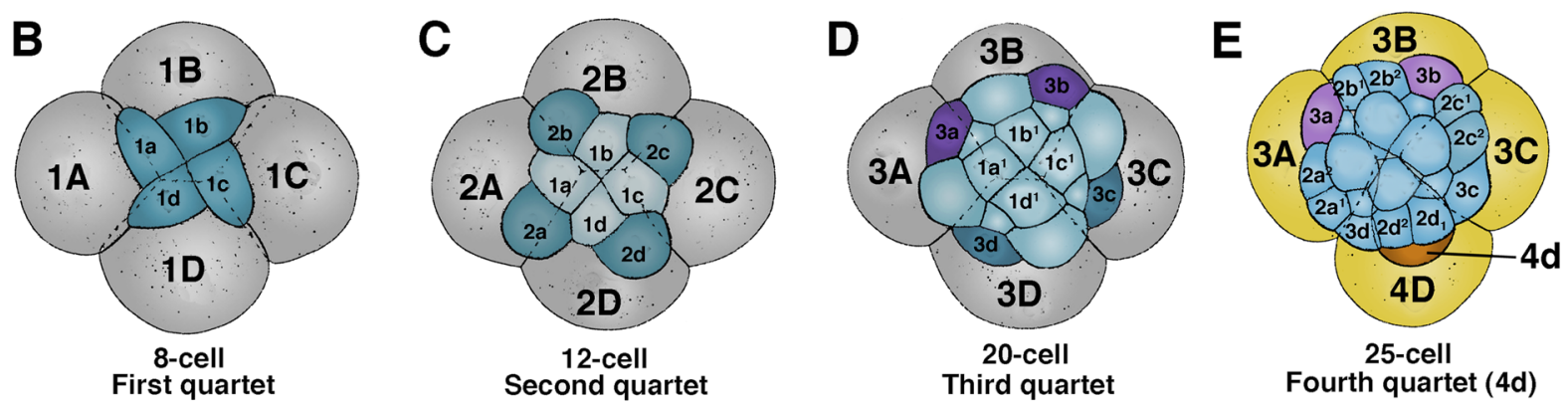

Fourth quartet (4d)

Ectomesoderm

Endomesoderm

Endoderm

G

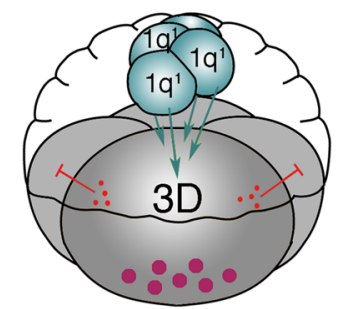

Specification of 3D Lateral Inhibition MAPK, ?
H

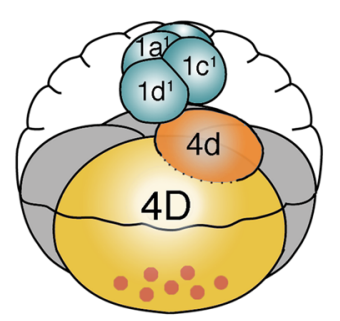

D quadrant specified

Birth of $\mathbf{4 d}$

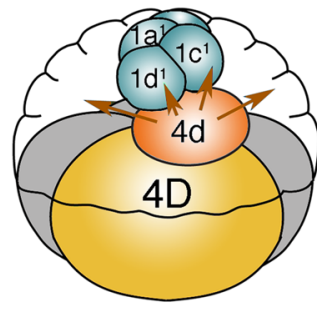

Activity of the organizer, 4d

? 


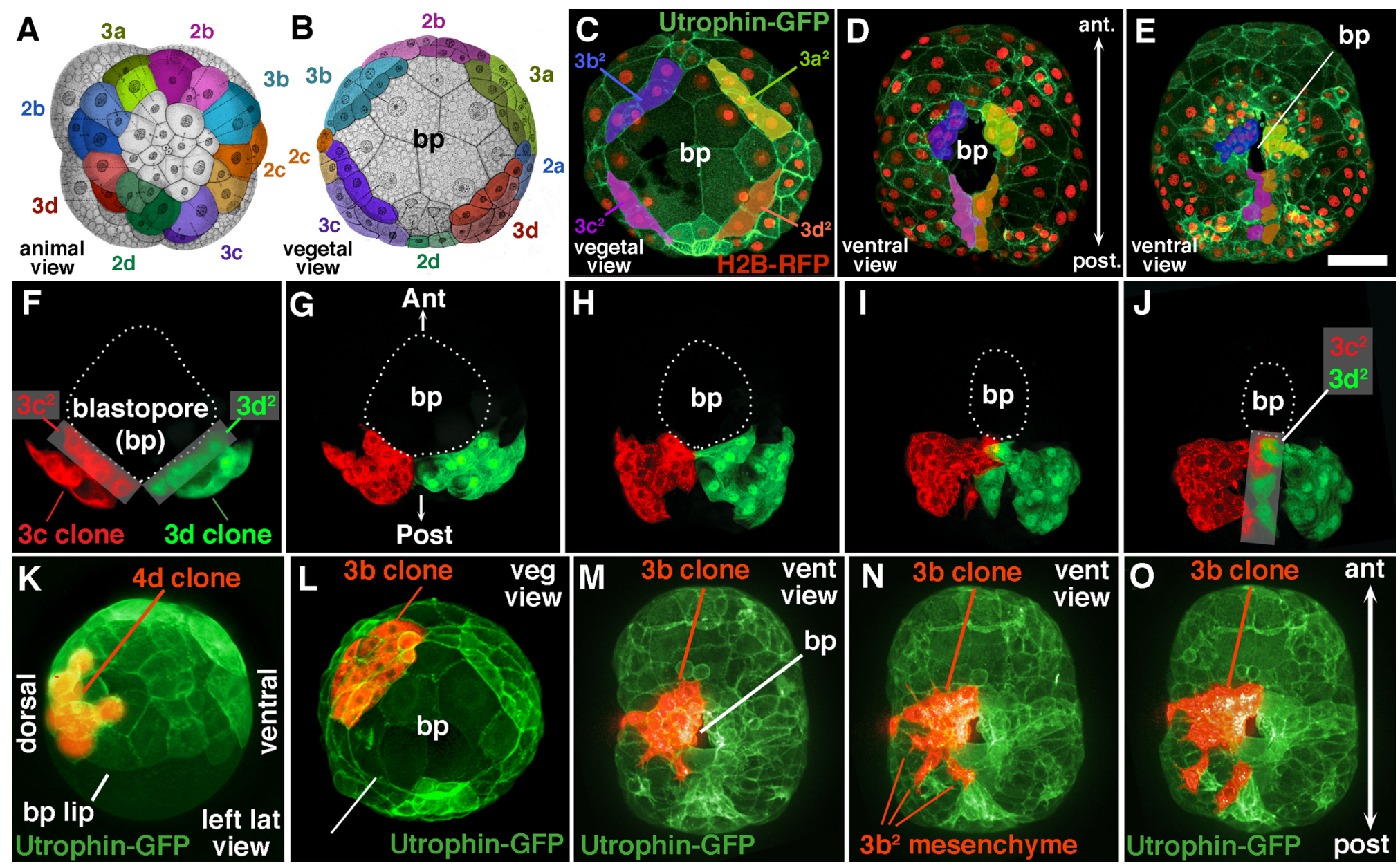


figure 5
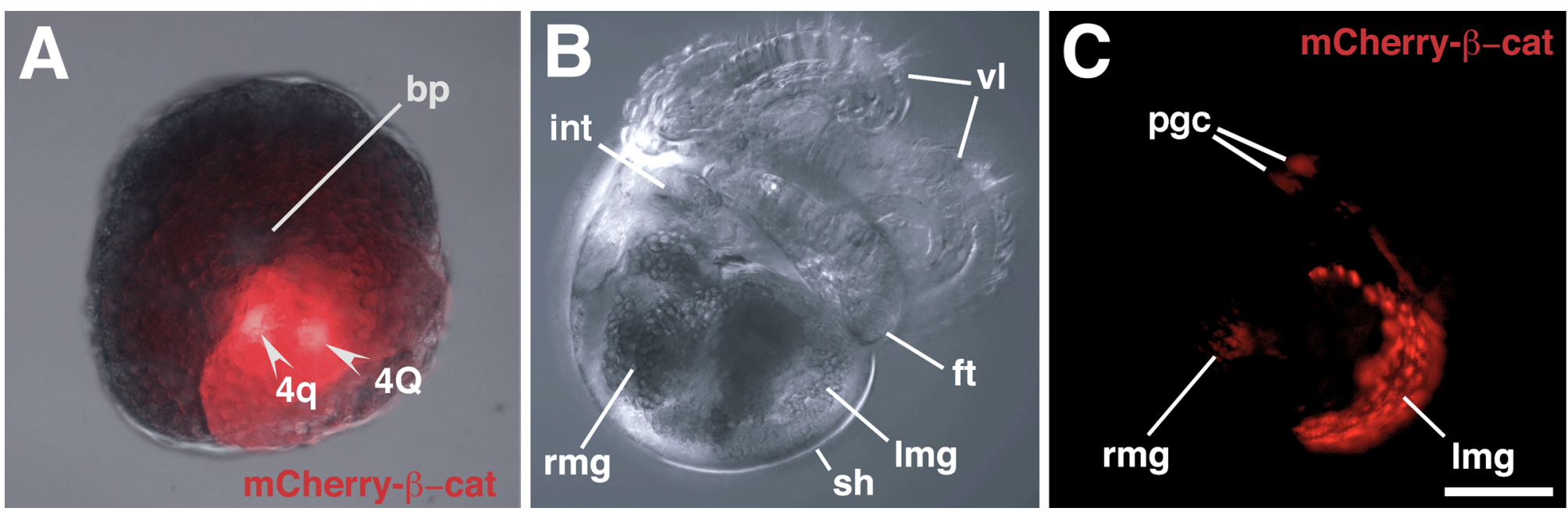